\title{
Music comprehension in the light of some ideas of hermeneutic theory
}

\section{Tania Burdeva}

Chair of Music, Faculty of Education, Plovdiv University P. Hilendarski, Plovdiv, Bulgaria

\section{Email address:}

tburdeva@abv.bg

\section{To cite this article:}

Tania Burdeva. Music Comprehension in the Light of Some Ideas of Hermeneutic Theory. International Journal of Literature and Arts. Special Issue: Musical Theory, Psychology and Pedagogy. Vol. 2, No. 5-1, 2014, pp. 65-69. doi: 10.11648/j.ijla.s.2014020501.21

\begin{abstract}
The paper examines some philosophical and psychological aspects of the understanding of music. The approach of hermeneutics to the problems of understanding gives reasons to connect the specific act of understanding music with the general theory of understanding. The current paper is an attempt to find the points of contact between "the commonly accepted rules" of the understanding and the understanding of music.
\end{abstract}

Keywords: Music Comprehension, Hermeneutics

\section{Introduction}

Understanding of works of music is part of a wide range of sensory, emotional and cognitive processes. True spiritual enjoyment of music as the most abstract art requires going into the deeper layers of the work of art, that lie beyond the sensory immediacy. Along with this the understanding of a musical work suggests making it part of the world of the recipient - of his cultural and historical consciousness, his intellectual and emotional outlooks. This defines a different look at the matter of understanding the art of music, including it in the philosophical and psychological context of the concept of understanding. The reason to consider some philosophical and psychological aspects in understanding the art of music is rooted in the attempts of the science of philosophy to discover and formulate common principles and postulates of understanding and its universal models.

The phenomenon of "understanding" has its broader dimension in various philosophical aspects of the problem of reflection of reality in general and more narrowly - in each particular field of knowledge, including knowledge of art. The theory of understanding is called hermeneutics. The word is of Greek origin and means "explanation", "interpretation". In the literature, hermeneutics is defined as:

- Theoretical basis for the exegesis of written monuments (W. Dilthey).

- Art, method, or theory for understanding and interpretation of texts, and generally of all linguistic phenomena - speech and written sources, the language of poetry and fiction, the language of science ( $\mathrm{J}$. Fogeler)

- Theory about the extraction of the spiritual meaning of the text (F. Ast)

- Doctrine of interpretation, a set of rules and theoretical postulates governing the interpretation of a specific text or a set of signs that can be considered for specific text, including literary and artistic works (P. Ricoeur)

- General Methodology of the Humanities (E. Betti, P. Winch, W. Dilthey)

- Universal methodology on cultural phenomena (F. Ast)

\section{Subject, Purpose and Objectives}

\subsection{The Purpose of this Research}

The purpose of this research is to clarify the concept of understanding and on this basis to reveal the contents of the term "understanding music" in its relationship with the general concept of understanding. Finding the common grounds could be used in music pedagogy for implementing a system of pedagogical approaches to manage perception of music. 


\subsection{Understanding as a Problem in Philosophy, Psychology and Art History}

Hermeneutics is the science that has been studying the problems of interpretation, understanding and explanation of the various historical and religious texts, legal documents, works of literature and art from antiquity till modern times. The interest in hermeneutical concept has been growing since the seventies of the twentieth century. Through hermeneutics art studies focus on the phenomena in art in view of their cultural context. It represents the semantic content relevant to the work of art. In this sense, hermeneutical approach to the problems of understanding allows us to connect the specific act of understanding of music to the general theory of understanding. The idea of the universality of the phenomenon of understanding offers the opportunity to seek its much narrower implementation in a specific science, such as musicology. The hermeneutical idea itself is mainly in directing interpretation towards the inner meaning of the work.

Fr. Schleiermacher raised the idea of developing a common, universal hermeneutics that considers understanding as a universal phenomenon in human life. $\mathrm{He}$ defines general hermeneutics as theory of the art of understanding, which establishes a system of general rules applicable in various fields of knowledge. The system of universal rules is based on clear principles derived directly from nature of thought and language. Hence the two methods of interpretation - grammatical and psychological. The art of understanding lies, on one hand, in the penetration in the spirit of the language, and on the other hand - in the originality of the author. The two aspects of understanding grammatical and psychological, are inseparably joined together as are inseparable general and specific, language and personality. Grammatical interpretation according to Fr. Schleiermacher is the art to find a specific meaning in each speech, starting from language and using language. Through it we may understand the work by analyzing the language, and in particular its component parts (units). Grammatical interpretation is oriented towards determining the importance and meaning of language units.

Psychological interpretation opens the possibility of transition from objective language in the work to subjective speech of the author, to reconstruction of the author's personality. Only through psychological interpretation it is possible according to Fr. Schleiermacher to understand the subjective basis of all linguistic modifications of the author, to understand the course of his thoughts. The process of psychological interpretation - he says - must begin with a study of the decision and the idea of the author.

\subsection{Different Aspects of Understanding in Music Teaching}

In terms of music, grammatical interpretation can be understood as finding the meaning of the musical speech, recognition of expressive meaning in specific musical means of expression in the work, finding logic in combining musical intonation units to form a specific, logically complete musical thought.

When it comes to participation in musical activities this means the utilization of a specific type of logic - musical logic, expressed by means of musical language. Grammatical interpretation as an analysis of the components of language can definitely be associated with the analysis of each of the elements of the musical work, whose unity is an expression of the logic in building musical imagery. According to P. Mintcheva the musical logic is expressed by the pitch and rhythm organization of the tones, and its perception and realization is associated with finding the emotional content of the melody and the understanding of the characteristic intonation style. Music influenced mainly by the melody, which combines elements of musical speech and is a logical musical thought, built up of different in pitch and duration tones organized in intonation nuclei with a certain structural and mood meaning. Here's what E. Hanslik says on the themes of a piece of music:" Here we have the principal theme; the true topic or subject of the entire composition. Everything it contains, though originated by the unfettered imagination, is nevertheless the natural outcome and effect of the theme which determines and forms, regulates and pervades its every part. We may compare it to a self-evident truth which we accept for a moment as satisfactory, but which our mind would fain see tested and developed, and in the musical working out this development takes place analogously to the logical train of reasoning in an argument. The theme, not unlike the chief hero in a novel, is brought by the composer into the most varied states and surrounding conditions, and is made to pass through ever-changing phases and moods " everything, no matter what contrasts it may present, is conceived and formed in relation to the theme“. , Това е главната тема - истинският материал и съдържание (предмет) на цялото тоново произведение. Всичко в него е свободна последователност и въздействие на темата, обусловено и оформено, овладяно и изпълнено чрез нея. Тя е самостойна аксиома, която наистина удовлетворява за момента, но бива оспорвана от духа ни, който иска да види развито това, което аналогично на едно логическо развитие, става в музикалното осъществяване. Композиторьт въвежда темата подобно главната фигура в един роман, в различни положения, обстановки, променливи успехи и настроения - всичко друго, дори да е контрастиращо, е премислено и създадено във взаимовръзка с нея" [7, p. 117].

Grammatical interpretation implies analysis of the means of expression, which define the image and emotional nature of a musical theme. The following reasonings refer to the main theme of the Coriolanus Overture by Beethoven. The bright, embossed image sounds dramatically, powerfully and strongly. This impression is created by the set of means of expression that builds the thematic structure: abrupt, massive chords in quarters, followed by a return to the tonic in long note values, breaks filled with dramatic 
tension, as if creating a moment of "suspense", ascending melodic line, strong dynamics (fortissimo). And yet another example - the theme at the beginning of the Opus 90 Impromptus in E-flat Major by F. Schubert. The composer achieved the elegance of this music piece through a steady rhythmic motion, the gradual unfolding of melody without jumps, chromatic sequences, legato strokes, dynamic nuances of "piano" dynamics. The listener must differentiate these composite units of the musical work in order to characterize the themes and on this basis to follow and understand the overall development of the musical theme, that underlies the musical image.

The psychological interpretation, leading to an understanding of the subjective basis of linguistic modifications of the author, is related to the penetration into the specifics of intonational style of the respective composer. Because each artist, depending on his aesthetic taste and the trend to which he belongs, makes his individual choice for combining and transforming popular musical means of expression, which marks the originality and uniqueness of his musical imagery. Every composer has an original style, his own way and approach of using musical expressions, reflecting the logic of his musical ideas, and achieving this logic is the way to learning a musical work. In the context of "creative logic" P. Mincheva states that when we find the logic of the musical ideas of the author, the logic in combining musical expressions, in the unfolding of a musical form, then we can say that we understand the work.

Each author's style is characterized by the specifics of its musical thematics. Analyzing the musical thematics we can reveal the individual characteristics of the style of the composer. The construction of the musical themes gives ample opportunities for the incorporation of a rich variety of images. These opportunities are huge with regard to the details that characterize the creative personality of the composer, and which the listener has to search, find and know in order to understand and go deeper into the artistic nature of the work. For example, the Unfinished Symphony by F. Schubert is an example of his song thematics, distinguished by originality and uniqueness and revealing the specifics of his musical thinking. The intense and conflict thematic development is alien to the song nature of Schubert's musical themes. The characteristics of excited lyrics and singing in the main theme of the first part, the texture and details of the accompaniment, show the influence of the vocal lyricism of Schubert. The theme is performed by a flute and a clarinet, whose timbre richness is complemented by a particularly expressive accompaniment which plays an important role in the set of means of expressions. All this, together with the harmonious development gives this music excitement and spirituality. The second theme reserves the imaging and genre of the main theme, but brings some danceability too. The cellos performing it create timbre contrast to the first theme. Accompaniment is dominated by syncopated rhythm, and the texture is homophonic and has a greater transparency. The second theme is widely developed.

This brief look at the first part reveals one of the most characteristic features of the song thematics of Schubert treating topics not as short structures, but as finished melodic song spheres. The music-literate listener must analyze and know all these manifestations of the composer's style, revealing the unique originality, individuality and compositional and technical characteristics, in order to understand fully the detailed musical imagery.

All attempts of theoretical rationalizing of the process of understanding are based on the teachings of $F$. Schleiermacher. Contemporary hermeneutical theories are based on his universal hermeneutics. According to one of the most significant representatives of philosophical hermeneutics of the twentieth century H. Gadamer: "The understanding and the interpretation of texts is not merely a concern of science, but obviously belongs to human experience of the world in general... The phenomenon of understanding not only pervades all human relations to the world. It also has an independent validity within science, and resists any attempt to reinterpret it terms of scientific method... Hence the human sciences are connected to modes of experience that lie outside science: with the experiences of philosophy, of art, and of history itself. These are all modes of experience in which a truth is communicated that cannot be verified by the methodological means proper to science." „Разбирането и тълкуването на текстове не е само необходимост за науката, а очевидно принадлежи към човешкия опит изобщо... Феноменът на разбирането не само пронизва всички човешки връзки със света. Той има самостоятелна валидност и в науката, като се противопоставя на опита да се превърне в научен метод... Така науките за духа се преплитат с видове опит, лежащи извън науката: с опита на философията, с опита на изкуството и с опита на самата история. Всички те са видове опит, в които се оповестява истина, невъзможна за верифициране с методическите средства на науката“" $[6$, p. 11, 12].

\subsection{Theory of Hermeneutic Circle Relative to Music Perception}

The purpose of interpretation directed toward adequate impact on the realization of the text and its meaning is closely related to the notion hermeneutic circle. The principle of the hermeneutic circle receives its theoretical understanding in the attempts to identify the mechanisms of the process of understanding. F. Schleiermacher formulates exactly the principle of the hermeneutic circle as one of the basic principles of his universal hermeneutics whereby "for the understanding of the whole, it is necessary to understand its components, but for understanding of the components it is necessary to create awareness about the meaning of the whole (e.g. the word is a part of the sentence, the sentence is part of the overall text, the text is a part of the creative heritage of an author, etc.)". "3a разбирането на цялото е необходимо да се разберат неговите отделни части, но за разбирането на отделните 
части вече е необходимо да се има представа за смисъла на цялото (думата е част по отношение на изречението, изречението е част по отношение на текста, текстът е част по отношение на творческото наследство на даден автор и т. н.)“ [1, p. 641]. The notion of the hermeneutic circle reveal the dialectical nature of the relationship between the whole and its parts in the process of understanding. According to G. Ruzavin the dialectical nature of the interaction between the parts and the whole in the process of interpretation testifies to the relative nature of all understanding. According to this concept of the hermeneutic circle, the parts are understood according to the whole to which they are related, and whose meaning they present, and the whole - from the inner harmony of its constituent parts, from the clarification of the meaning of the parts and their relationship to each other. In this sense, understanding, according to Schleiermacher, is a basic operation of referencing and comparison. For example, the words in a sentence are not unequivocal as they acquire one meaning or another depending on the context of the whole sentence, i.e. they are relative to the meaning of the whole sentence. On the other hand, the understanding of the meaning of the sentence depends on the understood meaning of each component word (part). Based on the dialectical relationship between the parts and the whole, each word gives specific meaning of the preceding, specifying the meaning of the whole sentence and vice versa. In this most common example in the literature illustrating the hermeneutic circle, we find the following contradiction: what is to be understood, must be already known. Certain knowledge of the object of understanding is necessary. This knowledge Schleiermacher called minimal fore-knowledge or fore-understanding which is a prerequisite for the jump in the hermeneutic circle.

E. Shulga discovers the meaning of the hermeneutic circle in the fact that it reflects a process whose moving principle is constantly occurring and resolving of the contradiction between the understood whole and the parts specified with its help, between understanding the main problem and a detailed explanation of all its contents.

After Fr. Schleiermacher, the analysis of the process of understanding through the principle of the hermeneutic circle is continued by W. Dilthey. He developed another aspect, according to which the understanding of the text is only possible with understanding of the spiritual world of the period. Dilthey further sought understanding in the relationship between the work of art and the whole body of works of the respective author.

The idea concerning the part - whole relation in more specific terms is present in the analysis of music works necessary for their full perception and understanding. A musical composition is a complex system of multi-components, each of which is logically connected with the integrity of the composition and is an overall structure of subordinate semantic units. Understanding of musical logic is connected on the one hand with the understanding of the musical means of expression as separate units with a specific meaning in the system of expressions in the musical work (melody, measure, rhythm, tempo, timbre, strokes, dynamics, harmony, texture), which in its turn is possible only with the perception of the integrity of the structure. "The connection of the elements of the musical piece is reversible so far as each of the distinguished expressions can be mentally isolated for a moment to explain its meaning” „Свързването на елементите в цялостно музикално произведение е обратим процес дотолкова, доколкото всяко от осъзнатите изразни средства може мислено да се изолира за момент, да се обясни значението му" [8, p. 66].

The clarification of the dialectical nature of the interaction between the parts and the whole in the process of understanding the musical work will be illustrated by the perception of the sonata form, whose parts (exposition, development, recapitulation) are understood by the listener according to the whole whose meaning they represent. The whole, on its part, is understood on the basis of explaining the importance of the three parts and the relationships between them. To better explain the presentation we will examine the first movement of Symphony No.4 of Brahms in the form of a sonata allegro. The imagery and emotional range goes from the state of restrained lyricism through a dramatic development gradually culminating to a tragic climax at the end of the movement.

These are the analytical actions that the listener performs and while doing so, he actually perceives and understands the arrangement of elements in the overall composition and the clear logic of the structure, its importance for creating the imagery and emotional content of the work. First, the image and emotional characteristics of the two themes of the exposition are determined, and expressions used to achieve them are analyzed. In the hierarchy of structural elements the whole-part relation is first examined in the relations exposition - themes and themes-expressions. The main theme is of a controversial type and consists of three thematic nuclei. The lyrical expression in the first of them is achieved through the initial expressive intonation and long-duration tones. The second intonation nucleus in the main theme creates a contrast in terms of the metro-rhythmic pattern and the melody is a persistent repetition of a motif within the octave. A new thematic core appears in the final stage of the theme, balancing the tension from previous parts by a gradually descending melodic movement and even rhythm. The second theme is built on cantillenic, melodious intonations that add brightness and lyric to the theme. The timbre - it is performed by cellos and horns, gives a touch of warmth and intimacy. The development is comprehensive, developing in full the possibilities of the thematic material. Starting with an unusual complete presentation of the main theme, it is built on intensive development of motifs from both themes, with modulations to distant keys. The recapitulation starts in an original way - after the fading movement in the development, the beginning of the main theme is conducted in twice as long tonal durations. It is performed by woodwinds with the accompaniment of 
strings and timpani in muted tremolo. Gradually, the main theme returns to its original form. In the recapitulation both themes are presented in the same sequence as in the exposition, but in the main tonality. The coda gives the culmination of the first movement. The closing becomes the end result of the development and outcome of the dramatic action. In the area of culmination the first thematic nucleus of the main theme appears again, where it sounds spectacular and monumental. Here appear again the motifs from the second and third intonation nuclei of the main theme, which already fully altered bring a dramatic expression and power.

In general, this it is the analysis that a reasoning and understanding listener performs to reveal the meaning of each meaningful element, comprising the widely developed sonata form of this first movement, based on the conflict between and development of contrasting dramatic themes, under the influence of the main theme.

\section{Conclusions}

1. The connection of the specific act of understanding music with the general theory of understanding opens up opportunities for a more in-depth understanding of the works of musical art.

2. The theories of hermeneutic circle and grammatical interpretation indicate the analytical operations which reasoning and understanding listener performs to reveal the meaning of each element in a musical work.

3. Certain ideas of the hermeneutic theory can be used for the development of a musical educational system for understanding the meaning of the musical means of expression.

The mediation in the understanding of works of music requires reflecting on the semantic relationships between the worlds of art, psychology and philosophy. This text is an attempt to find and interpret the points of contact between generally accepted rules of understanding and understanding of the music piece. The approach of dialogue between disciplines, which is the subject of this paper, can contribute to the clarification of the process of understanding music.

\section{References}

[1] Dictionary of Philosophy, 1993 (Философски речник, 1993)

[2] Dilthey W. Contemporary Culture and Philosophy, in Kulturologia. Vol. 2, 1993 (Дилтай, В. Съвременната култура и философията, в кн. Културология, т. 2, 1993)

[3] Fogeler, J. History and stages of evolution of philosophical hermeneutics, in Hermeneutics: History and the Present, 1985 (Фогелер, Я. История возникновения и этапь эволючии философской герменевтики, в кн. Герменевтика: история и современность, 1985

[4] Gabitova, R. The universal hermeneutics of Friedrich Schleiermacher, in Hermeneutics: History and the Present, 1985 (Габитова, Р. Универсальная герменевтика Фридриха Шлейермехера, в кн. Герменевтика: история и современность, 1985)

[5] Gadamer, H.G. Introduction to Truth and Method, in Kulturologia, Vol.2, 1993 (Гадамер,Х-Г. Въведение към Истина и метод”, в кн. Културология, т. 2, 1993)

[6] Gadamer, H.G. Truth and Method 1997 (Гадамер, Х. Г. Истина и метод, 1997)

[7] Hanslik, E. The Beautiful in Music, 1998 (Ханслик, Е. За музикално красивото, 1998)

[8] Mincheva, P. Music and Intellect, 1994 (Минчева, П. Музиката и интелектът, 1994)

[9] Ricoeur, P. Text as a Model: Hermeneutic Understanding, in Kulturologia, Vol.2, 1993 (Рикьор, П. Текстьт като модел: херменевтичното разбиране, в кн. Културология, т.2, 1993)

[10] Rusavin, G. Problems of understanding and hermeneutics, in Hermeneutics: History and the Present, 1985 Рузавин, Г. Проблема понимания и герменевтика, в кн. Герменевтика: история и современность, 1985

[11] Shulga, E. A problem of hermeneutic circle and dialectics of understanding, in Hermeneutcs: History and the Present, 1985 (Шульга, Е. Проблема „герменевтического круга“ и диалектика понимания, в кн. Герменевтика: история и современность, 1985) 